\title{
Storying Ruptures as Educational Practice
}

\author{
Heather Greenhalgh-Spencer ${ }^{1}$ (D ) Zofia Zaliwska ${ }^{2}$
}

Published online: 15 September 2018

(c) Springer Nature B.V. 2018

\section{Staying with the Trouble}

The state of Oklahoma uses curriculum, in their Science courses, that has largely been developed by oil and gas industry leaders. ${ }^{1}$ The curriculum fosters confusion around whether or not climate change exists, and the causes of climate change. In the state of Idaho, legislators, teachers' groups, parent groups, and various activist groups are fighting over whether or not climate change should be mentioned in any of the Science curricula in the state. ${ }^{2}$ In 2016, when the state of Idaho was pushed to update their decades-old Science standards, many school leaders pushed for the adoption of standards that reflected national guidelines on scientific knowledge. There was a backlash to this, and all sections on climate change were completely removed from the curricula. Various groups then joined the fight, and now Idaho is still conflicted about what to put in the curriculum, whether or not to mention climate change, and whether or not to mention extinctions of animals and habitat. In the state of Texas, the Texas Natural Gas Foundation had a large part in forming the Texas Science standards and curricula. According to one reporter from The Houston Chronicle, the foundation was given power to shape the ways that climate change is discussed:

Here's the problem: it largely ignores climate change and global warming. By relegating a global environmental crisis to a supplementary teacher's guide, the curriculum turns its back on the facts. Science, not industry cheerleading, is what is needed in the classroom. In a ham-handed attempt to sway public opinion, the curriculum describes solar and wind power as "perceived" renewable energy sources and says there is a "debate" about whether using renewable sources is better for the environment. Instead of contemplating a gradual shift to renewable energy, the curriculum

1 Banerjee and Lee (2017).

2 Albeck-Ripka (2018).

Heather Greenhalgh-Spencer

Heather.greenhalgh-spencer@ttu.edu

Zofia Zaliwska

http://www.zofiazaliwska.com

1 Department of Curriculum and Instruction, Chair of Graduate Work in Blended and Personalized Learning, College of Education, Texas Tech University, 3008 18th Street, Lubbock, TX 79409-1071, USA

2 Ontario Institute for Studies in Education, University of Toronto, Toronto, Canada 
describes the ending of nonrenewable energy as "devastating to us socially as well as economically."3

Students in Texas classrooms will be given the impression that there is considerable debate over what can be done, and what has caused climate change. And they will further be given the impression that shifting to renewable energy will be bad for people.

It is into this socio-political landscape that Donna Haraway brings insights and practices that are meant to help us, as her readers, re-think how we fit into our world, how we might learn from and coexist with others (humans, non-humans, natural forces), and how we might change our practices through the telling of new kinds of stories. In Staying with the Trouble, Haraway ${ }^{4}$ challenges us to ponder on the ways we think about and talk about (tell stories about) how humans access and shape the material world.

The papers in this special issue each provide an educator's response to Donna Haraway's book Staying with the Trouble. Haraway's book is timely, in that it draws our focus to the temporalities, materialities, and ideologies that conjure our current reality, offering new and more responsible modes for our pedagogical practices. Haraway writes: "We-all of us on Terra-live in disturbing times, mixed-up times, troubling and turbid times. The task is to become capable, with each other in all of our bumptious kinds, of response". She situates these disturbing times as belonging to a particular historical moment, pointing out that we live "in the midst of the earth's sixth great extinction event and in the midst of engulfing wars, extractions, and immiserations of billions of people and other critters for something called 'profit' or 'power' - or, for that matter, called 'God'". ${ }^{6}$ Living in the midst of these events generates apathetic attitudes of despair, a "game over attitude" that Haraway argues "is facilitated by various kinds of futurisms". 7 She explains:

In urgent times, many of us are tempted to address trouble in terms of making an imagined future safe, of stopping something from happening that looms in the future, or clearing away the present and the past in order to make futures for coming generations. Staying with the trouble does not require such a relationship to times called the future. In fact, staying with the trouble requires learning to be truly present, not as a vanishing pivot between awful or edenic pasts and apocalyptic or salvific futures, but as mortal critters entertwined in myriad unfinished configurations of places, times, matters, meanings. ${ }^{8}$

Thus, Haraway calls for us to examine our thoughts, actions, practices, and assumptions, in the present; to make trouble and make a difference in the present, and not dream of some faraway future. By focusing on the present, Haraway also foregrounds the temporality and materiality of the 'now'. We, her readers, are encouraged to think through new ways of being together on the planet, and new practices to invoke in order to make that possible. She urges us to respond in ways that eschews futurism, asking us to reconsider our habitual understandings of past, present and future so that we can become impatient with cynicism, despair and neoliberal affirmations: "Our task is to make trouble, to stir

\footnotetext{
3 The Editorial Board of The Houston Chronicle (2018).

4 Haraway (2016a).

5 Ibid. p. 1.

6 Ibid. p. 4.

7 Ibid. p. 4.

8 Ibid. p. 1.
} 
up potent response to devastating events, as well as to settle troubled waters and rebuild quiet places". 9 We understand her request as multimodal, where response becomes destabilized from its human-centric understanding of business-as-usual, an understanding that has kept ethics and accountability from attending to relationality in more complex terms. Haraway untethers response from classical causality, suggesting from the very beginning of her introduction that response is a simultaneous act of making trouble and responding to trouble. It is only through this vital understanding of response that we can offer something more liveable. The vitality of her request also implies a need for sustaining the temporalities and materialities of this task. Response to the trouble is a matter of staying with the trouble that we are making. Response in this context thus resists notions of answerability, self-certainty and efficiency, encouraging instead a process of learning to pay attention to the material details "of that which is normally held still in order to do that which one thinks one is doing". ${ }^{10}$ Response as an act of learning to pay attention in the midst of making trouble produces something new. This cannot be done alone or in isolation, but is necessarily a becoming-with.

Haraway plays with the idea of kin. Her world view is based on the notion that all creatures, human and non-human, as well as all forms of matter, comprise our kin. It is only by learning to live together in new ways-Haraway invokes the concept of symbiogenesisthat we can save each other and Terra. Haraway also foregrounds the idea of sympoiesis to provoke us, as readers, into recognizing the ways that we are always in the process of making our world, and always making it together with other creatures, matter, and timeframes. Staying with the trouble is part of the making together and new forms of living together that, Haraway argues, are needed. So, how do we 'stay with the trouble?'

Haraway uses stories-fiction, non-fiction, science fiction, scientific reports told as stories-in order to see our world differently. Her use of stories is meant to prompt us, as readers, to examine our actions, rethink, and re-act, to new ways of making our world together with others. She also uses metaphors, etymology and figures to prompt this same type of active pondering. For Haraway, figures and tropes "are what make us want to look and need to listen for surprises that get us out of inherited boxes"11 they are "materialsemiotic nodes or knots in which diverse bodies and meanings coshape one another". ${ }^{12}$ The telling of stories through such tropes tangles the dimensions of "imagined possibility" and "ordinary reality," which in turn require response. Storytelling is thus a method that simultaneously makes and responds to our present in troubling ways. But it is a method amidst many. What matters is the how-ness of the response and thinking about the details, the materialities and temporalities that build our response. As Haraway echoes throughout Staying with the Trouble:

It matters what matters we use to think other matters with; it matters what stories we tell other stories with; it matters what knots knot knots, what thoughts think thoughts, what descriptions describe descriptions, what ties tie ties. It matters what stories make worlds, what worlds make stories". ${ }^{13}$

\footnotetext{
9 Ibid. p. 1.

10 Haraway (2014).

11 Haraway (2003).

12 Haraway (2008).

13 Haraway (2016b).
} 
Caring for these details of mattering is perhaps the most important lesson to take away for us. Following Haraway, "how to address the urgency is the question that must burn for staying with the trouble". ${ }^{14}$ This is not only an invitation for educators to re-vision their practices, but an opportunity to put to work Haraway's proposition, something that the field of education is uniquely equipped for. How might these stories of the anthropocene gather us? What might these stories be? What might they make? Telling different stories of the anthropocene through educational theorizing, concept building and methodological experimentations, educators hold a unique and critical position for "composting-as-we-go."

\section{Staying with the Trouble as an Educator and Philosopher}

A recent review of textbooks in the U.S. shows that only half portray climate change as being caused by human activity. ${ }^{15}$ Furthermore, the textbooks that do portray climate change as connected to human activity often do not describe near-term consequences of climate change. For example, the sixth extinction, and the relational causes of climate change, are never mentioned. A report by The Globe and Mail argues that Canada is in the midst of a debate over how and what to teach about First Nations people, habitat, and industrial encroachment. ${ }^{16}$ A report by The Atlantic notes that Pearson Education, and textbooks and curricular materials created by Pearson, are being influenced by groups with connections to oil, gas, coal, and conservative parent groups. When these parent groups were asked about their lobbying efforts, many parents noted that they wanted to make sure that kids were told 'the truth'. The article quotes parents:

Children are so vulnerable in their younger years and what they hear they believe is truth," said Karin Gililland, another volunteer with the coalition. "Truth is what this is all about. We want truth.

Emily McBurney echoed that concern: "I'm afraid that [teaching climate change] is instilling fear in children at a very young age that either we're going to run out of something or overpollute the Earth. I didn't want them to come away with the wrong impression of America."17

There is an appeal to "truth" being made by many stakeholders within the field of education. Questions about what counts as truth, how we come to know truth, and how truth (or truths) get taught in school, are ripe for further studies and consideration by philosophers of education.

Furthermore, the insights in Staying with the Trouble link to other projects in philosophy of education such as 'pedagogy of discomfort,' ambiguity, and the "unfinished projects of freedom" described by pragmatists and poststructuralist traditions. If, as Haraway suggests, communication between and among multiple species is key to better avenues of survival, what does this mean for the ethical and pedagogical responsibilities of the "educator as politician" ? If stories and metaphors must become our tools for thinking, as Haraway suggests, then what implications might this have for theories on 'habit of mind'. Such

\footnotetext{
14 Ibid. p. 6.

15 Meehan et al. (2018).

16 Stueck and Alphonso (2017).

17 Foran (2014).
} 
questions arise within the all-too-real contexts of contemporary political, social, environmental, and economic crises that threaten planetary life. These crises demand rethinking our fundamental relationship to one another but also to nature, to the earth, environment, and other-worldly imaginings that reshape the here and now. Multiplicity, contradiction, irony, connectivity, and ambiguity take precedence over certainty, independence, autonomy, and boundaried selves.

Haraway guides toward a fundamental rethinking of relationships through the use of stories and metaphors. She urges us - as readers and participants in the world-to (re)consider the thoughts we use to think other thoughts; the stories we use to tell other stories, and the relationships we use to form other relationships. These touchstones, borrowed from Haraway's book, also inform the ways we understand the articles in this issue.

\section{It Matters What Thoughts Think Thoughts}

Haraway argues that it matters what thoughts we use to think through — to generate- other thoughts. The authors in this special issue take up this theme in various ways. GreenhalghSpencer contends that we must take care with how we choose to talk about and convey 'facts' in our classrooms. The existence of 'facts' has become controversial, and this political moment should shape how we talk about science, fact, and truth. Boler and Zaliwska talk about the ways that philosophy, and various forms of philosophical thought, breed particular ways of looking at the world. Philosophical thought engenders certain habits of mind that carry over into how we make sense of our world. Springgay deploys the metaphor of 'felt' - both the feeling and the fabric - to guide the reader toward considering how a 'felting' of thought might be productive. Truman uses Haraway's 'speculative fabulation' as a way to rethink qualitative research methods, and the ways that these methods can lead to 'new lines of flight' as well as neoliberal thought paths. Stengel adopts a 'diffractive' reading of Spinoza, in concert with both pragmatism and Haraway's new materialist feminism, in order to ruminate on the types of thought and action that are right for this political moment.

\section{It Matters What Stories We Use to Tell Other Stories}

Haraway shows us the importance of stories, and the ways that it matters what stories we use to tell other stories. Storytelling can be part of cementing the status quo, but it can also be part of 'making trouble,' stirring up a response, and rebuilding relationships. Springgay tells us the story of writing on rocks; of the ways that 'rock-felting' can lead to stories that are 'felt' in a new way. Truman considers that ways that speculative fiction can be linked to research writing and research methods. When we engage in research, and call it research do we name our work as something that links into messy lives, factual accounts, situated knowledge, or 'clean' social science? Greenhalgh-Spencer ruminates on the interrogative ability of critical storytelling. She wonders if critical storytelling can help us, as readers, to consider facts, knowledge, and how we come to know what we know. Boler and Zaliwska create a re-conceptualization of hope, and use storytelling as a map for the making of new concepts in philosophy. Stengel considers the ethics of storytelling, and what goes into our stories. She deploys the concept of 'composting-as-we-go' to get at the ways that stories involve multiple standpoints and realities. 


\section{It Matters What Relations We Use to Create Other Relations}

Haraway asks us to consider what modes of relating can lead to 'causing trouble,' 'staying with the trouble,' 'responding to trouble,' and rebuilding both relationships and material connections. Stengel expands on Haraway's concept of 'stringing' as a form of relationship building. Stengel 'strings' together philosophical standpoints as a way of creating relationships between theories and practices. Boler and Zaliwska consider relationship building as part of a pedagogy of discomfort and a pedagogy of grief. Springgay considers 'intimate transmaterial' relationships that can be built up between humans and landscape objects. Truman uses the concept of 'lures,' and stories as 'lures' that can connect us to new ways of thinking. She considers the power of stories to 'grab' us and reinforce dominant narratives, or 'trouble' our assumptions. Greenhalgh-Spencer contemplates the ways that visceral stories and ethnographic practices can connect readers to material realities that exist outside of their lived experience. All of the authors envision ways that philosophy, storytelling, and pedagogy can connect people with each other, and can strengthen ties between human, non-human, and the natural world.

We hope you take the articles in this special issue as a connection point to new ways of thinking, telling, and relating to others (human, non-human, matter) in your own praxis and ways of being in the world. We hope, too, that these articles create a moment for pondering how to best teach thoughts, tell stories, and coexist with others in this world at this 'troubled' socio-political moment.

\section{References}

Albeck-Ripka, L. 2018. Idaho stripped climate change from school guidelines. Now it's a battle. The New York Times. Feb. 6, 2018. https://www.nytimes.com/2018/02/06/climate/idaho-schools-climate-chang e.html.

Banerjee, N., and J. Lee 2017. Science teachers respond to climate materials sent by Heartland Institute. Inside Climate News. Dec. 22, 2017. https://insideclimatenews.org/news/22122017/science-teachersheartland-institute-anti-climate-booklet-survey.

Foran, C. 2014. The plan to get climate-change denial into schools. The Atlantic. Dec. 8, 2014. https://www. theatlantic.com/education/archive/2014/12/the-plan-to-get-climate-change-denial-into-schools/38354 $0 \%$.

Haraway, Donna. 2003. Situated knowledges: The science question in feminism and the privilege of partial perspective. Turning Points in Qualitative Research: Tying Knots in a Handkerchief 2003: 21-46.

Haraway, D. 2014. Anthropocene, Capitalocene, Chthulucene: Staying with the trouble. Antrhopocene: Arts of living with a damaged planet. AURA: Aarhus University Research on the Anthropocene.

Haraway, Donna Jeanne. 2008. When species meet, vol. 224, 4. Minnesota: University of Minnesota Press.

Haraway, Donna J. 2016a. Staying with the trouble: Making kin in the Chthulucene. Durham: Duke University Press.

Haraway, Donna J. 2016b. Staying with the trouble: Making kin in the Chthulucene, 29. Durham: Duke University Press.

Meehan, Casey R., Brett L.M. Levy, and Lauren Collet-Gildard. 2018. Global climate change in US high school curricula: Portrayals of the causes, consequences, and potential responses. Science Education 102 (3): 498-528.

Stueck, W., and C. Alphonso. 2017. Changing history. The Globe and Mail. Nov. 12, 2017. https://www. theglobeandmail.com/news/national/education/history-canada-indigenous-education/article36157403/.

The Editorial Board of The Houston Chronicle. 2018. Science, not oil and gas cheerleading, is needed in Texas classrooms. The Houston Chronicle. Jul. 25, 2018. https://www.houstonchronicle.com/opinion/ editorials/article/Science-not-oil-and-gas-cheerleading-is-needed-13102106.php. 